\title{
Letter: In response to a recent letter by Prior et al.
}

Citation for published version (APA):

van der Beelen, S. H. E., Agten, S. M., Suylen, D. P. L., Wichapong, K., Hrdinova, J., Mees, B. M. E., Spronk, H. M. H., \& Hackeng, T. M. (2021). Letter: In response to a recent letter by Prior et al. Thrombosis Research, 207, 66-66. https://doi.org/10.1016/j.thromres.2021.06.017

Document status and date:

Published: 01/11/2021

DOI:

10.1016/j.thromres.2021.06.017

Document Version:

Publisher's PDF, also known as Version of record

Document license:

Taverne

Please check the document version of this publication:

- A submitted manuscript is the version of the article upon submission and before peer-review. There can be important differences between the submitted version and the official published version of record.

People interested in the research are advised to contact the author for the final version of the publication, or visit the DOI to the publisher's website.

- The final author version and the galley proof are versions of the publication after peer review.

- The final published version features the final layout of the paper including the volume, issue and page numbers.

Link to publication

\footnotetext{
General rights rights.

- You may freely distribute the URL identifying the publication in the public portal. please follow below link for the End User Agreement:

www.umlib.nl/taverne-license

Take down policy

If you believe that this document breaches copyright please contact us at:

repository@maastrichtuniversity.nl

providing details and we will investigate your claim.
}

Copyright and moral rights for the publications made accessible in the public portal are retained by the authors and/or other copyright owners and it is a condition of accessing publications that users recognise and abide by the legal requirements associated with these

- Users may download and print one copy of any publication from the public portal for the purpose of private study or research.

- You may not further distribute the material or use it for any profit-making activity or commercial gain

If the publication is distributed under the terms of Article $25 \mathrm{fa}$ of the Dutch Copyright Act, indicated by the "Taverne" license above, 


\section{Letter to the Editors-in-Chief}

\section{Letter: In response to a recent letter by Prior et al.}

\section{Dear Sir/Madam,}

Within this letter, kindly find below our response to the letter submitted by Prior and Butenas [1]. First and foremost, we would like to apologise for raising the suggestion that we had overlooked previous contributions to the development of FXIa assays. We would like to clarify our work and point of view in relation to the comments made by Prior and Butenas.

In their letter Prior and Butenas highlight several studies in which factor XIa (FXIa) and tissue factor (TF) were quantified using a newly developed assay based on prolongation of plasma clotting time upon addition of monoclonal antibodies against FXIa or TF [2]. This assay was later improved upon, and the same principle could be used to quantify FXIa in plasma and whole blood via a thrombin generation assay [3-5]. These studies have repeatedly shown correlations between procoagulant phenotype and increased FXIa concentration in circulation. We acknowledge the importance of these assays and their clinical impact, which emphasizes the importance of FXIa quantification in general.

The sample preparation of these assays, however, is similar to studies done by Loeffen et al., and is therefore susceptible to time-dependent FXIa-inactivation [6,7]. Stability experiments of FXIa in plasma showed a significant decrease in activity after $30 \mathrm{~min}$ (11\%), up to $38 \%$ after $120 \mathrm{~min}$ [6]. The instability of FXIa in plasma requires swift processing and analysis of samples for accuracy. This makes quantification of a large group of patients $(>1000)$ logistically challenging. The main focus of our proof-of-concept study is the development of an FXIa-assay that is independent of serpin inhibition and auto-inactivation. In our assay, a multivalent inhibitor is used to bind, protect and isolate FXIa from fresh blood samples [8].

Ultimately, optimization of this assay will allow direct addition of the multivalent construct to the blood collection tube with subsequent instantaneous binding and protection of FXIa from serpin inhibition and auto-inactivation during blood drawing. In the end a FXIa determination procedure is achieved that is independent of blood work-up and storage time.

It is evident that we and Prior and Butenas share similar goals. It is likely that this will result in a better understanding of FXIa and its role in cardiovascular diseases. However, the instability of FXIa in plasma due to serpin-inhibition and auto-inactivation creates the need for a different and more dependable quantification strategy.

\section{Declaration of competing interest}

The authors declare that they have no known competing financial interests or personal relationships that could have appeared to influence the work reported in this paper.

\section{References}

[1] S. Prior, S. Butenas, Letter: in response to a recent article by van der Beelen et al.1, Thromb. Res. 202 (2021 Jun 1) 104.

[2] S. Butenas, A. Undas, M.T. Gissel, K. Szuldrzynski, K. Zmudka, K.G. Mann, Factor XIa and tissue factor activity in patients with coronary artery disease, Thromb. Haemost. 99 (1) (2008 Jan) 142-149.

[3] S.M. Prior, M.J. Cohen, A.S. Conroy, M.F. Nelson, L.Z. Kornblith, B.M. Howard, et al., Correlation between factor (F)XIa, FIXa and tissue factor and trauma severity, J. Trauma Acute Care Surg. 82 (6) (2017 Jun) 1073-1079.

[4] J.W. Shupp, S.M. Prior, D.Y. Jo, L.T. Moffatt, K.G. Mann, S. Butenas, Analysis of factor XIa, factor IXa and tissue factor activity in burn patients, Burns J. Int. Soc. Burn Inj. 44 (2) (2018 Mar) 436-444.

[5] S.M. Prior, K.G. Mann, K. Freeman, S. Butenas, Continuous thrombin generation in whole blood: new applications for assessing activators and inhibitors of coagulation, Anal. Biochem. 15 (551) (2018 Jun) 19-25.

[6] R. Loeffen, R. van Oerle, P.G. de Groot, J. Waltenberger, H.J. Crijns, H.M.H. Spronk, et al., Increased factor XIa levels in patients with a first acute myocardial infarction: the introduction of a new thrombin generation based factor XIa assay, Thromb. Res. 134 (6) (2014 Dec) 1328-1334.

[7] R. Loeffen, R. van Oerle, M.P.G. Leers, J.A. Kragten, H. Crijns, H.M.H. Spronk, et al., Factor XIa and thrombin generation are elevated in patients with acute coronary syndrome and predict recurrent cardiovascular events, PLoS One. 11 (7) (2016 Jul 15), e0158355.

[8] S.H.E. van der Beelen, S.M. Agten, D.P.L. Suylen, K. Wichapong, J. Hrdinova, B.M. E. Mees, et al., Design and synthesis of a multivalent catch-and-release assay to measure circulating FXIa, Thromb. Res. 18 (200) (2021 Jan) 16-22.

S.H.E. van der Beelen ${ }^{a}$, S.M. Agten ${ }^{a}$, D.P.L. Suylen ${ }^{a}$, K. Wichapong ${ }^{a}$, J. Hrdinova ${ }^{\mathrm{a}}$, B.M.E. Mees ${ }^{\mathrm{b}}$, H.M.H. Spronk ${ }^{\mathrm{a}, \mathrm{c}}$, T.M. Hackeng ${ }^{\mathrm{a}, \mathrm{\prime}}$

${ }^{a}$ Department of Biochemistry, Cardiovascular Research Institute Maastricht, Maastricht University Medical Centre, Maastricht, the Netherlands

${ }^{\mathrm{b}}$ Department of Vascular Surgery, Cardiovascular Research Institute Maastricht, Maastricht University Medical Centre, Maastricht, the Netherlands

${ }^{\mathrm{c}}$ Internal Medicine, Cardiovascular Research Institute Maastricht, Maastricht University Medical Centre, Maastricht, the Netherlands

* Corresponding author.

E-mail addresses: s.vanderbeelen@maastrichtuniveristy.nl (S.H.E. van der Beelen), t.hackeng@maastrichtuniversity.nl (T.M. Hackeng). 